\title{
AUDIT KOMUNIKASI ORGANISASI LAYANAN AKADEMIK DI IAIN BENGKULU
}

\author{
Robeet Thadi \\ Fakultas Ushuluddin, Adab dan Dakwah, Institut Agama Islam Negeri Bengkulu \\ Jl. Raden Fatah Pagar Dewa, Kecamatan Selebar, Kota Bengkulu, Bengkulu, 38211, Indonesia \\ No. Telp./HP: 085267034449 \\ E-mail: robeet@iainbengkulu.ac.id
}

Naskah diterima tanggal 22 Januari 2020, direvisi tanggal 2 Mei 2020, disetujui tanggal 8 Mei 2020

\section{AUDIT COMMUNICATION ORGANIZATION ACADEMIC SERVICES IN IAIN BENGKULU}

\begin{abstract}
This study aims to evaluate the communication of academic services at IAIN Bengkulu. The research method used is descriptive qualitative case studies using communication audit approaches and models. The academic services communication audit at IAIN Bengkulu focused on evaluating the direction of communication flow, the forms of distribution, and media use. The data collection conduct through participant observation, in-depth interviews, and documentation. There were 12 research informants from the academic section, and then the data were analyzed for communication audit evaluations. The direction of academic service information flow takes place formally through vertical communication. The direction of information flow continues to flow from the head of the department to the academic staff and vice versa, horizontally at the same level and cross-channel people who are in diverse structures, and informally through a rumor. The direction of information flow has proceeded smoothly, although there are still obstacles to the lack of confidence of some of the Kasubbag and staff as an information delivery. Forms of disseminating academic service messages occur simultaneously and sequentially, simultaneously the distribution of academic service information and the selection of communication media is quite effective, but sequentially through written media and not yet effective. The results of this study at least contribute to the research of the field of organizational communication, especially the communication audit model on the communication evaluation model.
\end{abstract}

Keywords: communication audit, information flow, academic services.

Abstrak. Penelitian ini bertujuan mengevaluasi komunikasi layanan akademik di IAIN Bengkulu. Metode penelitian digunakan deskriptif kualitatif studi kasus menggunakan pendekatan dan model audit komunikasi. Audit komunikasi layanan akademik di IAIN Bengkulu fokus pada evaluasi arah aliran komunikasi serta bentuk penyebaran dan media yang dipakai. Pengumpulan data dilakukan melalui observasi partisipan, wawancara mendalam dan dokumentasi. Ada 12 informan penelitian dari bagian akademik, kemudian data dianalisis untuk evaluasi audit komunikasi. Arah aliran informasi layanan akademik terjadi secara formal melalui komunikasi vertikal arah aliran informasi berlangusung secara diadik mengalir dari kepala bagian hingga staf akademik dan sebaliknya, secara horizontal dalam level yang sama dan lintas saluran orang yang berada dalam struktur yang berbeda, dan informal melalui selentingan. Arah aliran informasi sudah berlangsung lancar meskipun masih ditemukan kendala adanya kurang percaya diri sebagian kasubbag dan staf sebagai penyampai informasi. Bentuk penyebaran pesan layanan akademik terjadi secara serentak dan berurutan, secara serentak distribusi informasi layanan akademik dan pemilihan media komunikasi cukup efektif, namun secara berurutan melalui media tulisan dan belum efektif. Hasil penelitian ini setidaknya berkontribusi dalam kajian bidang komunikasi organisasi khususnya model audit komunikasi pada model evaluasi komunikasi.

Kata kunci: audit komunikasi, arus informasi, layanan akademik. 


\section{PENDAHULUAN}

Perubahan status kelembagaan STAIN Bengkulu menjadi IAIN Bengkulu tahun 2013, berimplikasi dalam hal pengelolaan lembaga, baik bidang pendidikan, pengajaran, penelitian maupun pengabdian pada masyarakat. Implikasi perubahan bentuk ini terjadi restrukturisasi dalam pemberian layanan akademik, pada awalnya dikelola secara sentralistik kemudian berubah menjadi desentralistik.

Pola layanan akademik pasca restrukturisasi menajemen ini perlu dievaluasi, baik layanan yang diselenggarakan oleh bagian akademik di tingkat rektorat maupun fakultas, karena seringkali sumbatan-sumbatan komunikasi ditemukan. Dalam konteks komunikasi organisasi, peristiwa komunikasi tersebut dapat diselidiki melalui audit komunikasi. Audit komunikasi untuk melihat pengalaman dan memotret dalam dimensi komunikasi, diharapkan bisa menjelaskan mengapa komunikasi dalam unit, departemen, atau organisasi dari dimensi komunikasi tersebut sukses atau gagal.

Audit komunikasi dibutuhkan untuk mempelajari secara detil mengenai metode, objek dan subjek organisasi, tujuannya untuk memberikan masukan dalam menentukan perbaikan yang dianggap penting, melalui evaluasi pada gangguan dan hambatan komunikasi dari kemacetaan informasi dan hambatan komunikasi efektif. George Odiorne orang pertama yang memperkenalkan tentang audit komunikasi, menurutnya seperti dunia keuangan bahwa peristiwa komunikasi dapat dikoreksi, dievaluasi, dan dinilai secara cermat dan terstruktur (Morrisan, 2008).

Berbagai riset empiris tentang organisasi menurut Alex Bavelas dan Dermot Barett (1951), selalu berbicara prinsip-prinsip komunikasi efektif dalam kehidupan organisasi (Hardjana, 2016). Hardjana dalam risetnya tentang audit komunikasi internal, menemukan bahwa organisasi tidak dapat bekerja tanpa sistem komunikasi internal yang efektif. Namun dalam praktik sistem komunikasi internal penuh dengan persoalanpersoalan yang rumit (Hardjana, 2014).
Beberapa riset sebelumnya, audit komunikasi lebih fokus pada perusahaan atau lembaga pemerintah sebagai objek kajian, dimana telaah kajiannya audit komunikasi dalam meningkatkan kinerja dan kualitas kerja (Yuliyanto, 2015; Suprianto \& Rochmaniah, 2018). Audit komunikasi layanan akademik di perguruan tinggi menjadi penting, mengingat masih terbatas lembaga pendidikan terutama perguruan tinggi khususnya layanan akademik menjadi objek penelitian. Penelitian Hasmira misalnya, menggunakan metode survei untuk mengetahui penyebab dan solusi seringnya informasi yang berbeda dari BAAK dan Puskom UNP dalam konteks komunikasi lintas saluran (Hasmira, 2012). Empat penelitian baik Hasmira, Yuliyanto, Harjana maupun Suprianto dan Rochmaniah, samasama menjadi audit komunikasi sebagai objek telaah. Kebanyakan penelitian audit komunikasi memilih objek pada lembaga pemerintahan atau perusahaan, masih terbatas memilih lembaga pendidikan tinggi khususnya audit komunikasi layanan akademik.

Secara empiris dipilihnya layanan akademik di IAIN Bengkulu sebagai objek kajian komunikasi dilihat peneliti melalui audit komunikasi, yakni masih adanya ketidakpuasan sivitas akademika terhadap berbagai hal, seperti atasan, mahasiswa teman sejawat-sekerja, karena alasan-alasan tertentu. Pedoman layanan dan fenomena layanan akademik walaupun sudah diatur dalam rencana operasional, pedoman akademik, standar operasional prosedur dan kebijakankebjikan lain dalam layanan akademik. Ternyata, masih ditemukan beberapa kendala layanan seperti daftar ulang, registrasi mahasiswa, pembimbingan/dan konsultasi mahasiswa, serta job description masingmasing bagian.

Berdasarkan identifikasi masalah di atas, fokus penelitian audit komunikasi organisasi layanan akademik di IAIN Bengkulu pada pengalaman komunikasi keorganisasian dilihat dari arah aliran informasi dan bentuk media yang digunakan dalam memberikan layanan akademik kepada mahasiswa, dosen dan tenaga kependidikan. 
Tujuan penelitian ini untuk mengevaluasi bagaimana audit komunikasi organisasi layanan akademik di IAIN Bengkulu pada pengalaman komunikasi keorganisasian dilihat dari arah aliran informasi dan bentuk media yang digunakan. Penelitian ini berguna dalam memberikan referensi berupa evaluasi komunikasi internal organisasi, sekaligus membuka jalinan kerjasama yang lebih baik antara pihak institut dengan organisasi.

\section{LANDASAN KONSEP}

\section{Audit Komunikasi}

Seperti dikatakan Jane Gibson dan Richard Hodgetts, lingkup audit komunikasi merupakan analisis lengkap sutau organisasi pada sistem komunikasi internal dan eksternal, mulai dari masukan pada salah satu divisi hinggal iklim komunikasi organisasi (Hardjana, 2000). Kemudian Anthony Booth (1988) dari Inggris, dalam buku teknis berjudul The Communication Audit: a Guide for Managers memberikan gambaran dimana konsultan internal atau ekternal organisasi melakukan analisis atas bentukbentuk komunikasi di dalam organisasi dalam meningkatkan efisiensi organisasi (Hardjana, 2000).

Dua pendapat di atas menegaskan secara operasional ruang lingkup audit komunikasi pada komunikasi-komunikasi di dalam organisasi dengan tujuan untuk meningkatkan efisiensi organisasi melalui analisis yang menyeluruh tentang sistem komunikasi internal dan sistem komunikasi eksternal sebuah organisasi.

Di antara sejumlah tujuan penting yang banyak dikemukakan oleh para eksekutif untuk melakukan audit komunikasi, menurut laporan ICA Communication Audit dikemukakan Goldhaber dan Rogers upaya mendapatkan muatan informasi tentang gagasan, pengirim, dan media, serta nilai informasi dan kualitas komunikasi," karena muatan informasi yang overload ataupun underload menjadi sumber distorsi terbesar sistem komunikasi (Hardjana, 2000).

\section{Model Audit Komunikasi Organisasi}

Terdapat tiga model dominan audit komunikasi: pertama, model struktur konseptual, model audit komunikasi ini untuk melihat hubungan aspek tujuan, tata kerja atau prosedur operasional organisasi melalui pemanfaatan jaringan komunikasi fungsional, struktur, kebijakan dan kegiatan komunikasi. Model struktur konseptual dalam audit komunikasi memiliki pengaruh yang dominan dari model lainnya walaupun sulit dalam operasionalisasinya (Hardjana, 2000).

Kedua, model Profil Komunikasi Keorganisasian (PKK). PKK termasuk model analisis fungsional sistem organisasi, secara praktis dalam memeriksaan keadaan organisasi menggunakan pengetahuan dan ilmu sosial, tujuannya untuk memberikan solusi dalam memperbaiki kemacetan komunikasi yang terjadi untuk meningkatkan efektivitas organisasi.

Ketiga, model evaluasi komunikasi. Model ini memotret bagaimana praktik dan kegiatan komunikasi pada situasi tertentu, tujuannya hasil audit dapat dijadikan sebagai bagi pengelola organisasi dalam memperbaiki sistem komunikasi baik internal maupun eksternal pada perenacanaan dan pengendalian sistem komunikasi yang ada (Hardjana, 2000).

\section{Aliran Informasi Organisasi}

Proses aliran informasi dalam organisasi berjalanan secara dinamik, bagaimana pesan diciptakan, disebarkan dan diinterpretasikan. Menurut Guetzkow dalam Pace (2006) ada tiga cara informasi mengalir atau menyebar pada organisasi, yakni: penyebaran pesan secara serentak, penyebaran pesan secara berurutan dan penyebaran pesan secara serentak-berurutan.

Penyebaran pesan secara serentak, bahwa informasi/pesan didistribusikan secara bersamaan dengan sasaran yang banyak melalui media lisan dan tulisan dalam bentuk surat, pertemuan, rapat, televisi, atau teleconference. Kelebihan dari sifat aliran informasi ini dimana pesan dapat tersebar secara bersamaan pada banyak sasaran, namun karena bersifat terbuka maka penyebaran informasi yang bersifat rahasisa tidak bisa dilakukan. 
Penyebaran pesan secara berurutan, yakni proses distribusi informasi terstruktur, "siapa bicara kepada siapa". Informasi mengalir secara tidak bersamaan, komunikasi berlangsung antarpersonal, di mana informasi yang sensitif dapat terjamin kerahasiaannya, namun sering terjadi misinterpretasi dan prosesnya berjalan sedikit lambat. Sedang penyebaran informasi secara serentak dan berurutan, proses penyebaran pesan gabungan dari pola aliran pesan secara serentak dan berurutan.

\section{Arah Aliran Informasi dalam Organisasi}

Arah aliran informasi organisasi bagaimana pesan mengalir baik secara formal dari atasan kepada bawahan maupun informal dari bawahan ke atasan, secara horizontal berlangsung dalam level yang sama, sedangkan lintas saluran antarbagian fungsional berbeda.

Arah aliran informasi ke bawah, di mana pesan mengalir dari yang memiliki kedudukan lebih tinggi kepada bawahannya dan berlangsung secara formal. Menurut Pace informasi yang biasa dikomunikasikan yaitu: how to job, rationale for doing, organizational policies and practices, employee performance, dan mission of the organization (Pace, 2006). Sedangkan arah aliran informasi ke atas, informasi mengalir dari bawahan kepada atasan biasa berlangsung secara informal. Pentingnya komunikasi ke atas untuk memberikan masukan kepada pengambilan keputusan, memberikan masukan kepada atasan kapan bawahan siap menerima informasi, memberikan masukan kepada atasan tentang kondisi atau keluh kesah yang muncul, dan menumbuhkan rasa memiliki dan apresiasi serta menyumbangkan gagasan bagi keberlangsungan organisasi (Perbawasari \& Setianti, 2013).

Aliran informasi horizontal dalam organisasi berlangsung antara anggota organisasi yang memiliki kedudukan setara, dalam koordinasi beban tugas, koordinasi rencana kegiatan, memecahkan dan memperoleh pemahaman bersama dan menyatukan perbedaan mendapatkan dukungan interpersonal, dan komunikasi horizontal mencakup kontak antarpersonal (Masmuh, 2010).

Komunikasi lintas saluran dalam arah aliran informasi melewati batas-batas fungsional, misalnya anggota bidang satu staf berkonsultasi dengan ketua bidang lain mengenai tugas tertentu dan hal ini menjadi pantas dalam hubungannya dengan jabatan fungsional masing-masing. Sedangkan selentingan mengalir secara informal yang dilakukan oleh orang-orang dan peristiwa yang tidak mengalir melalui saluran formal, dalam konteks ini sumber informasi terlihat rahasia, meskipun informasi itu sendiri bukan rahasia.

\section{Pelayanan Akademik}

Dalam dunia pendidikan selain layanan administrasi yang paling sering didengar tentang pelayanan akademik. Kata pelayanan banyak digunakan dalam kehidupan seharihari, misalnya pelayanan publik, pelayanan administratif, pelayanan yang memuaskan dan sebagainya. Menurut Kotler dan Keller "Pelayanan akademik merupakan semua tindakan atau kegiatan yang dapat ditawarkan oleh satu pihak kepada pihak lain yang pada dasarnya tidak berwujud dan tidak menghasilkan kepemilikan apapun" (Kotler \& Keller, 2013).

Selanjutnya pelayanan akademik adalah segala kegiatan yang ditawarkan dan dilakukan oleh pihak akademik baik secara fisik maupun psikis serta pelayanan yang ditawarkan atau administrasi kepada siswa dan sivitas akademika yang lain, yang pada dasarnya tidak menghasilkan kepemilikan (Kotler, 2008). Pengertian pelayanan akademik dalam kurikulum pembelajaran menurut Rosita (2011) adalah upaya yang sistematis dari pendidikan untuk memfasilitasi peserta didik menguasai isi dari kurikulum melalui sebuah proses pembelajaran sehingga mereka mampu mencapai kompetensi standar yang diterapkan (Rosalina, Zati \& Ardiyanti, 2016).

Pakpahan dalam Susanto mengungkapkan kualitas pelayanan akademik merupakan perbandingan antara pelayanan akademik yang dirasakan pelanggan atau stakeholders dengan kualitas pelayanan akademik yang diharapkan pelanggan atau 
stakeholders. Apabila kualitas layanan akademik yang dirasakan sama atau melebihi kualitas pelayanan yang diharapkan maka pelayanan dikatakan berkualitas (Susanto, 2014; Thadi, 2019).

Berdasarkan uraian di atas, dapat ditarik simpulan bahwa, pelayanan akademik yaitu serangkaian aktivitas yang bersifat tidak kasat mata (intangible) dan kasat mata dari pihak institut kepada sivitas akademika khususnya mahasiswa yang melakukan proses registrasi, ujian, laporan nilai, dan sidang ujian akhir.

Adal lima jenis layanan mahasiswa dibidang akademik pada perguruan tinggi. Bidang kurikuler layanan tentang kebijakan dan peraturan akademik, sistem perkuliahan, manajemen kurikulum dan layanan lain dibidang kurikuler, kemudian bidang penelitian antara lain layanan pelaskanaan penelitian, buku pedoman penelitian dan publikasi hasil penelitian. Bidang pengabdian masyarakat layanan bidang pengabdian kepada masyarakat, bidang administrasi berkaitan dengan administrasi bidang akademik dan terakhir bidang ekstrakurikuler berkaitan dengan layanan di luar bidang kurikuler seperti pengembangan bakat dan minat mahasiswa, layanan kesehatan dan kesejahteraan mahasiswa (Tampubolon, 2001).

\section{METODE PENELITIAN}

Metode penelitian yang digunakan adalah deskriptif kualitatif dengan studi kasus yang berciri particularistic sebagai metode risetnya, dengan menggunakan pendekatan dan model audit komunikasi. Audit komunikasi layanan akademik di IAIN Bengkulu fokus pada evaluasi arah aliran komunikasi (mencakup komunikasi ke bawah, ke atas, horizontal, dan lintas saluran) serta bentuk penyebaran dan media yang dipakai dalam layanan akademik.

Penentuan informan dalam penelitian ini dengan menggunakan teknik purposive sampling. Teknik ini mencakup orang-orang yang diseleksi atas dasar kriteria-kriteria tertentu yang dibuat oleh peneliti berdasarkan tujuan penelitian (Kriyantono, 2008). Adapun kriteria yang ditentukan oleh peneliti adalah mengetahui alur pelayanan akademik dan terlibat secara langsung dalam lanyanan akademik, bersedia meluangkan waktu bersama peneliti untuk melakukan wawancara. Sesuai dengan kriteria informan kunci tersebut maka peneliti mendapatkan 12 informan yang dijadikan sebagai narasumber penelitian ini yakni 1 (satu) kepala bagian, 5 (lima) kasubbag, dan 6 (enam) staf akademik.

Pengumpulan data dilakukan dengan teknik wawancara mendalam, yaitu menggali informasi dari para informan dengan menggunakan panduan dan pedoman wawancara bagaimana berkomunikasi ke bawah (kabag dan kasubbag), bagaimana komunikasi ke atas (staf) dan bagaimana berkomunikasi dalam satu level, serta media apa yang efektif digunakan dalam layanan akademik. Untuk teknik pengumpulan data yang terakhir adalah pengumpulan dokumen baik dari proses wawancara yang dilakukan maupun data-data sekunder yang diperoleh peneliti dari studi literatur serta media-media yang digunakan oleh bagian akademik.

Data yang telah diperoleh dianalisis dengan tahapan reduksi, penyajian, penarikan dan verifikasi. Untuk melakukan keabsahan data, peneliti menggunakan triangulasi data, sumber, dan waktu.

\section{HASIL PENELITIAN DAN PEMBAHASAN}

\section{Arah Aliran Informasi dalam Layanan Akademik di IAIN Bengkulu}

Arah aliran informasi layanan akademik di IAIN Bengkulu dapat diuraikan melalui empat aliran informasi dalam organisasi yakni, komunikasi ke bawah, komunikasi ke atas, komunikasi horizontal, dan komunikasi lintas saluran.

Berdasarkan hasil wawancara yang peneliti lakukan terhadap informan mengenai arah aliran informasi layanan akademik di IAIN Bengkulu, tentang bagaimana aliran komunikasi ke bawah kepada para stafnya, diperoleh hasil yang hampir serupa antara jawaban yang satu dengan jawaban yang lainnya dari masing-masing informan terutama komunikasi atasan kepada 
bawahannya sebagai bentuk aliran vertikal dalam komunikasi organisasi.

Seperti hasil wawancara mendalam tentang informasi bagaimana cara melakukan pekerjaan layanan akademik yang disampaikan oleh atasan kepada bawahannya, sebagaimana dijelaskan oleh ibu Mamah Rahmah: "Biasanya kita menjelaskan kepada staf, tentang cara melakukan pekerjaan sebagaimana yang ada pada uraian tugas masing-masing, uraian tugas itu biasanya diturunkan dari job description masingmasing jabatan, secara praktis semestinya mekanisme pelaksanaan pekerjaan itu diuraikan melalui SOP, namun itu belum maksimal," (Rahmah, M. 2015, September 14).

Kemudian wawancara dilanjutkan, tentang aliran informasi yang berlangsung bila bagian akademik membutuhkan konsultasi dan koordinasi dengan bidang lain sebagai bentuk arus aliran informasi secara horizontal dan lintas saluran, Mamah Rahmah menjelaskan: "Pekerjaan ini tentu tidak bisa kita tuntaskan sendiri, karena ini kerja organisasi, untuk tugas yang sifatnya butuh koordinasi dengan bagian lain, biasanya langsung saya yang mengkoordinasikan, misalnya bagian humas dan kerjasama, bagian keuangan, salurannya bisa langsung bisa juga dengan surat, tergantung kualitas informasi dan data yang dibutuhkan, walaupun kita sedar sejauh ini terkadang masih ada kendala," (Rahmah, M. 2015, September 14).

Kemudian wawancara dilanjutkan dengan subbagian yang terlibat pada pelayanan akademik, Anwar Junaidi, mengungkapkan: "untuk melaksanakan tugas, kita menjelaskan kepada staf melalui uraian tugasnya masing-masing, sebenarnya cara melakukan pekerjaan itu harusnya sudah diuraikan dalam SOP, kita sudah pernah mendengar tapi belum ada sosialisasinya," (Junaidi, A. 2015, September 25).

Aliran informasi dalam organisasi tidak selamanya terjadi secara vertikal melalui downward communication dan upward communcition, tapi pada waktu-waktu tertentu melalui horizontal communication, dan cross-channel communication. Bila bagian membutuhkan koordinasi dan konsultasi dengan bagian lain, model komunikasi yang dikembangkan menurut Lukaman: "Bila itu antarstaf yang ada dalam fakultas biasanya langsung saja, tidak mesti birokrasi, bila ke bagian lain di luar fakultas biasanya kasubbag sendiri yang berhubungan, intinya pekerjaan yang dilakukan kita percaya pada penyelesaian ada di staf (Lukman, 2015 Oktober 1).

Sementara berkenaan dengan aliran komunikasi ke atas, bagaimana bawahan memberikan masukan atau saran serta mengungkapkan pikiran dan pekerjaan kepada rekan kerja dan organisasi, salah seorang informan, Isparina, menjelaskan: "Walaupun tidak setiap waktu, biasanya kita memberikan masukan dan gagasan baru disampaikan pada saat rapat-rapat, terkadang prosedur, namun biasanya juga kita secara informal menemui atasan untuk menyampaikan ide dan perasaan kita tentang pekerjaan," (Isparina, 2015 September 27).

Penjelasan beberapa informan penelitian, memberikan kepastian bahwa aliran komunikasi organisasi di IAIN Bengkulu, terutama bagian akademik aliran komunikasinya lancar, hal ini peneliti saksikan sendiri saat melakukan observasi tentang layanan akademik, baik atasan maupun bawahan tidak ada rasa canggung untuk menyampaikan dan meminta informasi berkaitan dengan pelaksanaan layanan akademik di IAIN Bengkulu.

Dalam audit komunikasi tentang arah aliran informasi, terdapat dua arah yaitu secara formal dan informal. Secara formal layanan akademik yang dilakukan bagian akademik IAIN Bengkulu melalui komunikasi vertikal (komunikasi ke bawah dan komunikasi ke atas), komunikasi horizontal dan komunikasi diagonal, sementara secara informal melalui selentingan.

Aliran komunikasi layanan akademik di IAIN Bengkulu dari atas ke bawah, informasi mengalir dari jabatan berotoritas lebih tinggi kepada mereka yang berotoritas lebih rendah yakni kabag hingga staf akademik, sebaliknya komunikasi dari bawah ke atas mengalir dari staf akademik, kasubbag menyampaikan informasi yang telah diperoleh kepada kepala bagian akademik. Pada komunikasi vertikal 
terjadi two ways communication, namun sifatnya sangat formal antara pimpinan dengan staf akademik.

Komunikasi ke bawah tentang layanan akademik kepada staf mengenai tata cara melaksanakan tugas, acuan dasar dalam melaksanakan tugas, aturan, dan aplikasi layanan akademik yang diterapkan organisasi, serta menumbuhkan nilai mencintai tugas kepada bawahannya dalam hal ini staf akademik dan kemahasiswaan di lingkungan IAIN Bengkulu. Sementara komunikasi ke atas mengomunikasikan beberapa hal kepada atasan, terutama melaporkan kepada atasannya tentang pekerjaan yang sudah dikerjakan, menyampaikan kepada atasan temuan dalam melaksanakan tugas dan fungsi yang belum mampu diselesaikan oleh staf, menyampaikan masukan kepada atasan sebagai bahan evaluasi pada bagian akademik atau IAIN secara keseluruhan dalam memberikan layana akademik kepada sivitas akademika khususnya mahasiswa.

Bagaimana aliran komunikasi vertikal (komunikasi ke bawah, dan komunikasi ke atas) dalam layanan akademik di IAIN Bengkulu dari audit komunikasi yang dilakukan proses komunikasi berlangsung lancar walau masih ada kendala tertentu, sejalan dengan apa yang dikemukakan Masmuh, di mana komunikasi vertikal merupakan proses komunikasi yang berlangsung dari atas ke bawah yang dikenal dengan downward communication dan dari komunikasi dari bawah ke atas atau upward communication yang terjadi secara timbal balik atau two way traffic communication yang berlangsung secara formal (Nurlita, 2012).

Selain secara vertikal, arah aliran informasi layanan akademik di IAIN Bengkulu juga berlangsung secara horizontal, komunikasi secara horizontal, merupakan komunikasi terjadi pada sesama fungsi dan pada tingkat jabatan yang setara. Komunikasi ini dapat mempermudah koordinasi yang dilakukan antarbagian, sehingga dalam memberikan pelayanan akademik, anggota internal organisasi dapat melakukan diskusi untuk menyelesaikan tugas tersebut.

Aliran komunikasi layanan akademik di IAIN Bengkulu secara horizontal, merupakan komunikasi terjadi pada sesama fungsi dan pada tingkat jabatan yang setara. Komunikasi ini dapat mempermudah koordinasi yang dilakukan antarbagian, sehingga dalam memberikan pelayanan akademik, anggota internal organisasi dapat melakukan diskusi untuk menyelesaikan tugas tersebut.

Komunikasi horizontal dalam layanan akademik terjadi manakala antar-kasubbag akademik baik di tingkat institut IAIN Bengkulu ataupun di fakultas menyampaikan informasi dalam bentuk koordinasi tugas pelayanan akademik, atau antarstaf yang berada di bawah otoritas atasan yang sama berbagi informasi bagaimana meyelesaikan tugas pelayanan akademik yang diberikan. Pernyataan ini sejalan dan mempertegas pernyataan Panghegar, bahwa sinkronisasi job desk sering terjadi sebagai akibat menumpuknya jenis pekerjaan yang sama pada level yang sama, sehingga kerjasama dalam menjalankan tugas menjadi kebutuhan baik secara formal dan informal terutama di level yang sama pada bagian akademik itu sendiri (Panghegar, 2013).

Sedangkan komunikasi lintas saluran dalam layanan akademik di IAIN Bengkulu, sering terjadi manakala staf akademik dan kemahasiswaan IAIN Bengkulu berbagi informasi dan saling melengkapi kebutuhan data pelayanan akademik dengan kasubbag akademik dan staf yang ada di fakultas. Komunikasi lintas saluran ini dilakukan dalam upaya menyampaikan informasi dengan menembus sekat-sekat fungsional masing-masing bagian.

Komunikasi lintas saluran dominan dilakukan oleh staf pada jabatan fungsional umum yang membidangi layanan akademik di IAIN Bengkulu, di sisi lain komunikasi lintas saluaran juga banyak ditemukan dilakukan oleh staf fungsional umum yang mengharuskan mereka berkonsultasi dengan bidang lain yang memiliki hubungan kerja dalam bidang akademik. Berdasarkan temuan ini, organisasi dalam hal ini IAIN Bengkulu penting memberikan pendidikan kepada staf untuk terampil dalam melakukan komunikasi lintas saluran melalui pelatihan komunikasi efektif.

Arah aliran informasi secara informal melalui selentingan atau komunikasi pribadi. 
Dalam dunia pendidikan terutama bidang layanan akademik, selentingan merupakan penyebaran pesan bidang akademik bersumber dari orang-orang yang menyebar dari sumber yang tidak diduga sebelumnya, informasi ini muncul dari mulut ke mulut, informasi tersebar secara cepat. Selentingan biasanya terjadi secara konsensus pada kelompok tertentu, bisanya sesorang yang berinsiatif dalam membagi infomasi cenderung menyiarkan dengan sasaran kelompok tententu dan jarang secara individu. Dalam layanan akademik misalnya sering ditemui disela-sela rapat ada yang menyampaikan informasi tentang model pelayanan akademik yang baru, padahal secara formal itu belum jelas dan pasti, tapi kebenarannya dapat dipercaya. Contoh lain misalnya tentang pemberlakukan KKNI, bila tahun 2016 perguruan tinggi belum memberlakukan KKNI maka akan mendapatkan sanksi.

Berdasarkan audit komunikasi yang dilakukan dalam proses layanan akademik di IAIN Bengkulu, aliran informasi berlangsung secara formal dan informal. Secara formal arah aliran informasi terjadi secara vertikal di mana informasi mengalir dua arah dari atasan kepada bawahan dan dari bawahan kepada atasan, aliran informasi terjadi secara horizontal antara bagian yang sama dalam mengoordinasi tugas, dan komunikasi lintas saluran. Sedangkan secara informal aliran informasi lanyanan akademik di IAIN Bengkulu melalui selentingan.

Jelasnya audit komunikasi organisasi layanan akademik di IAIN Bengkulu, arah aliran informasi secara prosedur terjadi secara formal melalui komunikasi vertikal yakni downward communication dan upward communication, melalui komunikasi horizontal dalam jejang dan jabatan sama, dan lintas saluran orang yang berada dalam struktur yang berbeda. Sedangkan secara informal, arah aliran informasinya melalui selentingan atau komunikasi pribadi.

\section{Bentuk Penyebaran Pesan dan Media Komunikasi Layanan Akademik}

Untuk mengukur efektivitas bentuk komunikasi dan media komunikasi yang dipakai dalam pelaksanaan layanan akademik di IAIN Bengkulu. Penelitian ini melakukan evaluasi/audit komunikasi tentang penyebaran dan pemilihan media komunikasi organisasi layanan akademik di IAIN Bengkulu.

Bentuk penyebaran pesan, dalam komunikasi organisasi bentuk penyebaran pesan ada tiga yakni: penyebaran pesan secara berurutan, penyebaran pesan secara serentak, serta penyebaran pesan secara serentak dan berurutan. Sedang media komunikasi organisasi dalam penyebaran informasi atau pesan biasanya melalui: tulisan saja, lisan saja, tulisan diikuti lisan dan lisan diikuti tulisan.

Berdasarkan hasil observasi partisipan, masih banyak persoalan yang dihadapi organisasi, terutama tentang penyebaran/distribusi informasi, bagaimana cara melaksanakan pekerjaan, dasar pemikiran dalam melaksanakan pekerjaan, kebijakan dan praktik-praktik organisasi yang disampaikan oleh atasan, bentuk penyebaran informasi dan pemilihan medianya belum tepat.

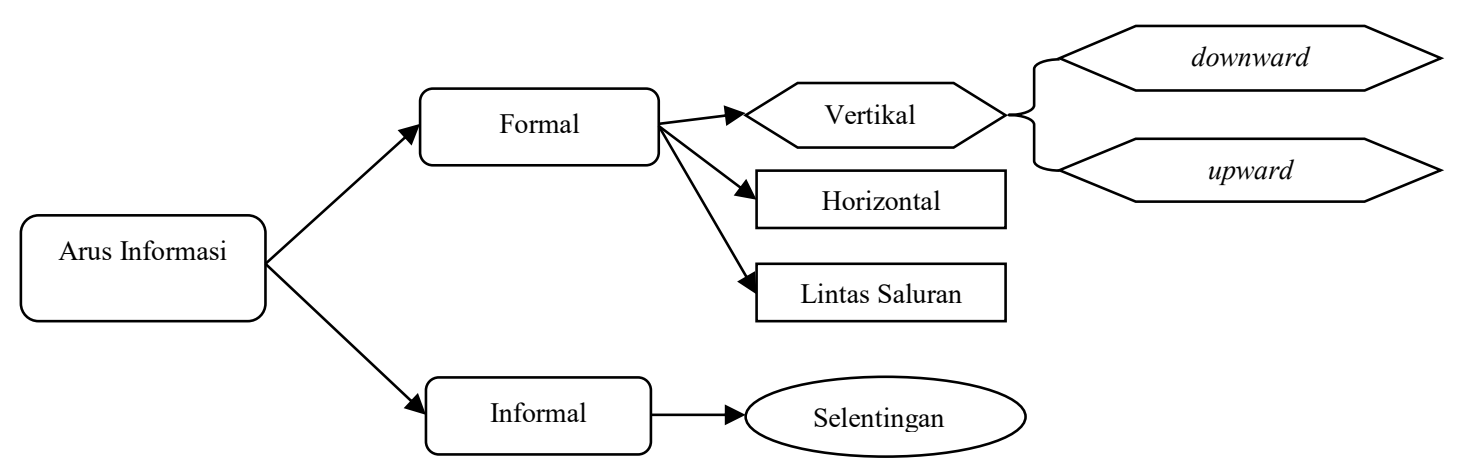

Sumber: Olahan Peneliti 
Apa yang peneliti peroleh melalui observasi ini, kemudian dilakukan crosscheck dengan bagian akademik dan ke mahasiswa yang ada di rektorat maupun di tiga fakultas, dan hampir semua informan memberikan jawaban yang sama. Penyebaran informasi peraturan, kebijakan, dan cara pelaksanaan pelayanan akademik, Kabag Akademik dan Kemahasiswaan IAIN Bengkulu, Ibu Mamah Rahmah, menjelaskan: "Informasi tentang pelaksanaan tugas, penyebaran kebawahan biasanya kita lihat dulu sifat pesannya. Selama ini kalau itu petunjuk pelaksanaan biasanya secara berurutan, apalagi kalau sifatnya melibatkan jabatan eselon, kalau yang praktis misalnya rapat-rapat, biasanya kita lakukan secara serentak, mediapun disesuaikan (Rahmah, M. 2015, September 30).

Lebih lanjut Mamah Rahmah menjelaskan, bawah sebenarnya secara internal, IAIN Bengkulu punyak petunjuk dalam pelaksanaan tugas, selain yang diatur dari pusat: "Sebenarnya kita ada job description, ada pedoman akademik dan ada SOP, tapi maaf belum tersebarkan secara merata. Media penyampaian pesannya masih terbatas, seperti buku petunjuk yang menggunakan media tulisan, jumlah cukup terbatas dan belum ada sosialisasi lengkap baik lisan maupun tulisan, informasinya masih terbatas," (Rahmah, M. 2015, September 30).

Sedangkan informan lainnya, salah satu Kasubbag Akademik di Fakultas Anwar Junaidi, ketika ditanya tentang ketersediaan acuan pelaksanaan tugas dan cara penyebarannya, beliau menjawab: "Uraian tugas masing-masing pegawai sudah punya dan sudah tersosialisasi dengan baik, demikian job description. Namun kadangkadang dalam menjalankan tugas, kita butuh peraturan, butuh acuan prosedur yang baku...ini saya belum bisa menyebarkan kepada bawahan, pernah mendengar kita ada SOP, ada pedoman akademik dan sudah dibukukan, tetapi informasi itu biasanya kita peroleh ketika ada rapat akademik dan rapat pimpinan, sudah saya sampaikan dalam bentuk lisan kepada bawahan, namun kita kesulitan karena bukunya tidak ada dan belum ada sosialisasinya," (Junaidi, A. 2015, September 30).

Lebih lanjut Anwar Junaidi, menjelaskan: "Penyebaran informasi dari atasan saya, informasi itu berkenaan dengan kebijakan organisasi hasil keputusan rapat, tapi tidak dibuat dalam bentuk peraturan atau bahkan salinan hasil rapat yang disebarkan, atasan hanya menyampaikan secara lisan saja, sehingga kita juga kesulitan untuk mengacunya dan menyampaikannya kepada bawahan" (Junaidi, A. 2015, September 30).

Selanjutnya tentang efektivitas media yang dipakai dalam penyebaran informasi layanan akademik, informan lain Isparina menjawab: "Biasanya kita sering diberikan informasi tentang bagaimana sebuah tugas dilakukan, biasanya kalau keputusan rapat kita dipanggil dan diarahkan oleh atasan, tapi kita tidak mendapatkan salinan secara tertulis. Namun kalo program atau kegiatan tersebut dari pusat biasanya ada panduannya sendiri, walaupun kadang-kadang kita cari sendiri di internet" (Isparina, 2015, September 30).

Kemudian peneliti menanyakan kepada informan yang berada pada level staf akademik, tentang pedoman akademik, SOP atau kebijakan lainnya, apakah dipahami isinya dan diaplikasikan dalam pelaksanaan layanan akademik. Mardiana, memberikan jawaban: "Kita pernah dengar tentang buku pedoman akademik, SOP, tapi jujur kita belum pernah tahu isinya seperti apa. Selama ini biasanya buku, SOP itu yang memiliki dan menyimpannya atasan, jarang tersampaikan kepada kita, walaupun dirapat pimpinan sering menyampaikan bahwa kita ada panduan akademik, ada SOP namun sosialisasi pemberlakuannya kepada kita masih sangat kurang," (Mardiana, 2015, September 30).

Informan lain, ketika ditanya hal yang sama menyoal tentang sosialisasi peraturan, pedoman, SOP maupun kebijakan organisasi, jawaban yang diberikan juga hampir sama, seperti yang disampaikan oleh Junidia Puspita Seri: "Kadang kita bingung sendiri menjawab pertanyaan mahasiswa, contoh yang barubaru ini tentang standar penentuan jumlah SKS mahasiswa pada saat mengisi KRS, apa menggunakan IPK atau IPS. Katanya di pedoman akademik IPS tapi kita IPK. Karena 
selama ini kita jarang sekali mendapatkan informasi baik dari atasan maupun sejawat sendiri tentang pedoman akademik, kiat pernah dengar ada pedoman tapi kita belum tahu persis isinya apa" (Sari, 2015, September 30).

Beberapa jawaban informan di atas, memberikan informasi dalam penelitian ini, bahwa penyebaran informasi dan pemilihan media yang dipakai dalam pelaksanaan layanan akademik cukup variatif, ada yang serentak, ada yang berurutan maupun serentak berurutan. Media penyebaran informasi pun, ada secara lisan, dengan tulisan, tulisan diikuti lisan maupun lisan diikuti tulisan.

Penyebaran pesan secara serentak, di IAIN Bengkulu Penyebaran dilakukan melalui media tertulis seperti surat, memo, pertemuan secara langsung, dan melalui media telekomunikasi (telepon dan SMS), sebagai salah satu cara yang digunakan oleh organisasi yang bertujuan untuk menyebarkan informasi kepada semua anggota secara serentak. Hal ini senada dengan pernyataan Ramadani, Lestari \& Susilo, bahwa pemanfaatan teknologi komunikasi seperti telepon, pesan singkat dan sistem jaringan komputer dapat memperlancar memperoleh pesan yang dibutuhkan, semua itu dapat membantu menghasilkan performa bagian dan staf organisasi yang ada (Ramadani, Lestari \& Susilo, 2015).

Penyebaran pesan dalam layanan akademik terjadi secara serentak, di mana bagian, subbagian, lembaga, atau unit lain mendapatkan informasi secara serentak atau bersamaan. Pada batasan ini distribusi informasi layanan akademik di IAIN Bengkulu dan pemilihan media komunikasi berlangsung efektif dan efisien, namun pada penyebaran pesan secara berurutan, sebagaimana kita ketahui pesan disampaikan secara berjenjang dan bersifat dua arah belum begitu efektif.

Bentuk penyebaran pesan ini membentuk perilaku atau budaya organisasi dalam distribusi informasi di IAIN Bengkulu khususnya pada layanan akademik. Secara spesifik pengulangan model penyampaian pesan melalui simbol-simbol baik secara lisan maupun tertulis berupa ide atau gagasan menghadirkan budaya organisasi dalam komunikasi organisasi (Alvian, 2016).

Baik arah aliran informasi, bentuk penyebaran pesan dan media yang digunakan dalam layanan akademik IAIN Bengkulu dapat memberikan pengaruh yang besar terhadap kualitas layanan yang ada. Pemaknaan akan informasi yang ada dalam memberikan layanan mulai dari bagimana informasi disampaikan, bagaimana informasi dimaknai dan bagaimana penerima informasi menciptakan pesan untuk orang lain menentukan efektivitas pesan itu sendiri.

Pembentukan, pengiriman, dan pemaknaan pesan layananan akademik menjadi tahapan dalam menyebarkan pesan layanan ke dalam organisasi secara menyeluruh. Aliran informasi dalam layanan akademik di IAIN Bengkulu terjadi secara berkesinambungan, bagaimana pesan diciptakan, ditampilkan dan diinterpretasikan oleh atasan dan bawahan dalam memberikan layanan akademik mahasiswa. Bentuk penyebaran pesan dan media yang digunakan juga akan membentuk budaya organisasi dalam iklim komunikasi organisasi khususnya dalam pemberian layanan akademik di IAIN Bengkulu.

Hasil audit komunikasi dalam pemilihan bentuk/media komunikasi yang digunakan oleh bagian akademik, bagaimana distribusi informasi berkenaan dengan layanan akademik terutama berkaitan dengan pedoman, panduan, kebijakan dan praktikpraktik organisasi ditemukan belum berjalan efektif. Masih ditemukan sumbatan aliran komunikasi melalui penyebaran informasi secara berurutan, karena pada level tertentu bagian akademik belum percaya diri untuk menyampaikan pesan secara bertahap.

Beberapa kasus sebagai temuan audit komunikasi dalam penelitian antara lain: pertama, secara fisik beberapa pedoman penyelenggaraan kegiatan akademik sudah dimiliki dan telah didistribusikan secara terbatas, namun belum optimal mampu disosialisasikan kepada pengguna/pemakai pedoman tersebut, seperti pedoman akademik dan SOP yang masih menyentuh level top leader pada setiap bagian, baik itu tingkat rektorat, fakultas, lembaga maupun jurusan dan program studi. 


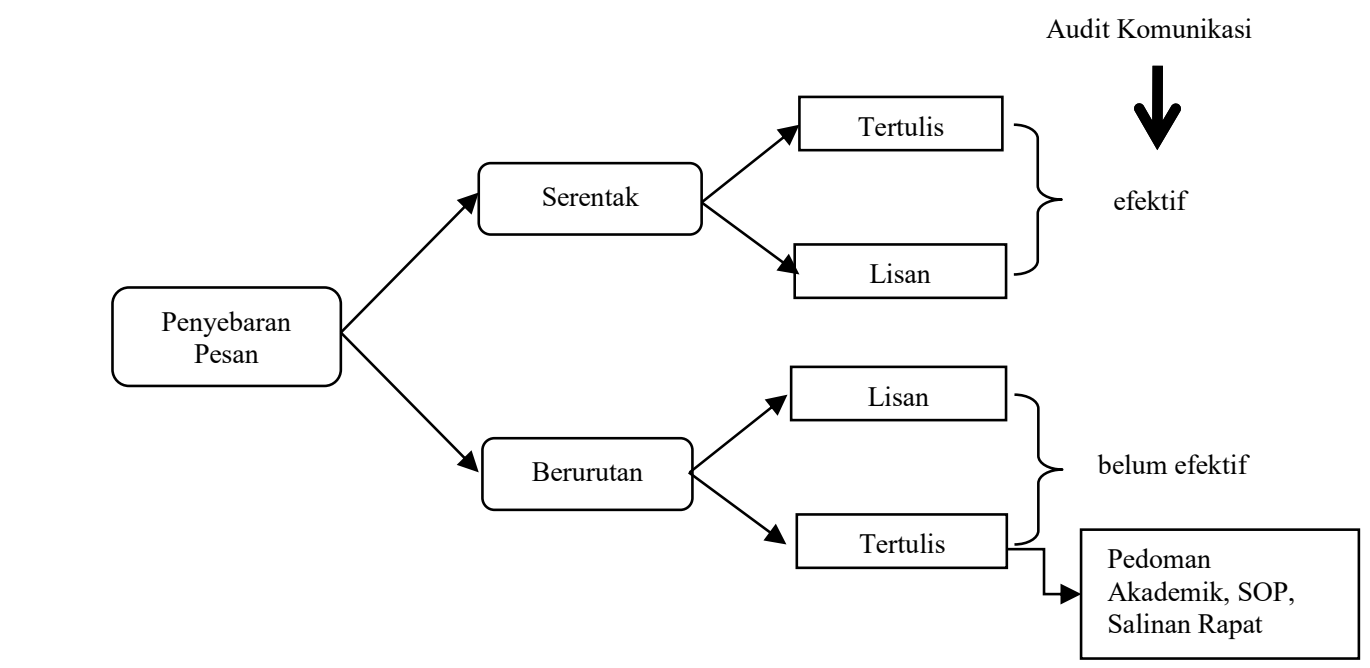

Sumber: Olahan Peneliti

Gambar 2. Efektivitas Bentuk Penyebaran Pesan dan Media Komunikasi Layanan Akademik di IAIN Bengkulu.

Kedua, penyebaran informasi secara berurut juga belum efektif, terutama tentang penyebaran hasil keputusan rapat-rapat yang berkaitan dengan kebijakan organisasi, dalam kesempatan tertentu sering kali atasan meyampaikan informasi tentang keputusan rapat, tetapi staf/bawahan terkadang sulit untuk menerjemahkannya dalam praktik organisasi, hal ini disebabkan belum terbiasanya organisasi dalam membuat salinan keputusan hasil rapat dan menyosialisasikannya. Artinya berdasarkan hasil audit komunikasi yang peneliti lakukan, ditemukan bahwa penyebaran informasi secara berurutan masih mengalami sumbatan, sehingga bentuk penyebaran pesan secara berurutan masih sering terjadi tidak efektif.

\section{PENUTUP}

\section{Simpulan}

Arah aliran informasi layanan akademik terjadi secara formal melalui komunikasi vertikal arah aliran informasi secara berlangsung secara diadik mengalir dari kepala bagian hingga staf akademik dan sebaliknya, secara horizontal dalam level yang sama dan lintas saluran orang yang berada dalam struktur yang berbeda, dan informal melalui selentingan. Arah aliran informasi sudah berlangsung lancar meskipun masih ditemukan kendala adanya kurang percaya diri sebagian kasubbag dan staf sebagai penyampai informasi.
Penyebaran pesan layanan akademik IAIN Bengkulu berlangsung dengan dua bentuk yakni serentak dan berurutan. Penyebaran pesan secara serentak dimana distribusi informasi layanan akademik dan pemilihan media komunikasi cukup efektif, namun penyebaran pesan secara berurutan melalui media tulisan dan belum efektif, sering terjadi terputusnya keberlanjutan arah aliran informasi, keputusan hasil rapat tentang kebijakan dan praktik organisasi sering disampaikan ke staf teknis, namun belum dituangkan dalam bentuk salinan keputusan rapat, akibatnya staf terkadang mengalami kesulitan untuk mengikuti keputusan tersebut karena belum bisa diacu secara tertulis. Hasil penelitian ini setidaknya berkontribusi dalam bidang komunikasi organisasi khususnya model audit komunikasi pada model evaluasi komunikasi.

Optimalisasi penyebaran pesan secara berurutan menjadi penting dalam layanan akademik, karena di sana berlangsung komunikasi antarpribadi. Demikian juga optimalisasi fungsi media komunikasi yang dipakai baik lisan maupun tulisan, sosialisasi pedoman penyelenggaraan organisasi menjadi penting, terutama pedoman akademik, standar operasional prosedur layanan, kebijakan dan praktik-praktik organisasi, yang selama ini baru menyentuh level pimpinan belum ke staf sebagai ujung tombak pelaksana teknis layanan penyelenggaraan pendidikan tinggi. 


\section{Saran}

Hendaknya setiap keputusan hasil rapat tentang kebijakan dan praktik organisasi dituangkan dalam salinan keputusan rapat yang didistribusikan ke setiap level organisasi untuk menghindari distorsi informasi dan salinan tertulis dapat dijadikan acuan dalam melaksanakan tugas layanan di perguruan tinggi khususnya IAIN Bengkulu.

\section{DAFTAR PUSTAKA}

Alvian, Y. (2016) Audit Mini Mengenai Kepuasan Komunikasi Organisasi di UD. Prima Jaya. Jurnal e-Komunikasi. [Online] 4 (2), 1-12. Available from: http://dewey.petra.ac.id/catalog/ft_detail.php ?knokat $=14586$.

Hardjana, A. (2000) Audit Komunikasi, Teori dan Praktek. Jakarta, Grasindo.

Hardjana, A. (2014) Audit Komunikasi Internal. InterAct. [Online] 3 (2), 1-17. Available from:

http://ojs.atmajaya.ac.id/index.php/fiabikom/ article/view/720.

Hardjana, A. (2016) Komunikasi Organisasi, Strategi dan Kompetensi. Jakarta, Penerbit Buku Kompas.

Hasmira, M.A. (2012) AUDIT KOMUNIKASI DI UNP (Kasus : Komunikasi Lintas Saluran Antara BAAK dan Puskom Universitas Negeri Padang). Humanus. [Online] 11 (1), 66. Available from: doi:10.24036/jh.v11i1.624.

Kotler, P. (2008) Manajemen Pemasaran. 12th edition. Jakarta, Indeks.

Kotler, P. \& Keller, K.L. (2013) Manajemen Pemasaran. Jakarta, Erlangga.

Kriyantono, R. (2008) Teknik Praktis Riset Komunikasi: Disertasi Contoh Praktis Riset Media, Public Relation, Advertising, Komunikasi Organisasi, Komunikasi Pemasaran. Jakarta, Kencana Prenada Media Grup.

Masmuh, A. (2010) Komunikasi Organisasi dalam Perspektif Teori dan Praktek. Malang, UMM Press.

Morrisan (2008) Jurnalistik Televisi Mutakhir. Jakarta, Kencana Prenadamedia Group.

Nurlita, I. (2012) Investigation of Organizational Communication Climate At Bhayangkara Surabaya University Using Communication Climate Inventory (CCI) Method. Academic Research International. 3 (2), 259-264.
Pace, W. (2006) Komunikasi Organisasi:Strategi Peningkatan Kinerja Perusahaan. Bandung, Remaja Rosdakarya.

Panghegar, S.F. (2013) Audit Komunikasi Organisasi Horisontal Departemen Front Office Singgasana Hotel Surabaya. Jurnal eKomunikasi. [Online] 1 (1), 183-184. Available from: http://publication.petra.ac.id/index.php/ilmukomunikasi/article/view/112/59.

Perbawasari, S. \& Setianti, Y. (2013) Komunikasi dalam Transformasi Budaya Perusahaan. Jurnal Penelitian Komunikasi. [Online] 16 (1), 1-12. Available from: doi:10.20422/jpk.v16i1.23.

Ramadani, D., Lestari, P. \& Susilo, M.E. (2015) Audit Komunikasi Organisasi Wahana Lingkungan Hidup Indonesia (Walhi) Yogyakarta. Jurnal ASPIKOM. [Online] 2 (4), 282. Available from: doi:10.24329/aspikom.v2i4.78.

Rosalina, D., Zati, M.R. \& Ardiyanti, D.A. (2016) Kajian Kepuasan Mahasiswa Terhadap Kualitas Pelayanan di Lingkungan Universitas Samudra. Jurnal Konsep Bisnis dan Manajemen. [Online] 3 (1), 26-33. Available from: http://ojs.uma.ac.id/index.php/bisman/article /view/235.

Suprianto, A. \& Rochmaniah, A. (2018) Audit Mini Komunikasi Quality Assurance (AKQUA) untuk Peningkatan Kinerja Karyawan PT Sinar Djaja Can. KANAL: Jurnal Ilmu Komunikasi. [Online] 5 (2), 141. Available from: doi:10.21070/kanal.v5i2.1482.

Susanto, A. (2014) Teori Belajar Pembelajaran di Sekolah Dasar. Jakarta, Kencana Prenadamedia Grup.

Tampubolon, D.P. (2001) Perguruan Tinggi Bermutu: Paradigma Baru Manajemen Pendidikan Tinggi Menghadapi Tantangan Abad Ke 21. Jakarta, Gramedia Pustaka Utama.

Thadi, R. (2019) Proses Komunikasi Instruksional dalam Pembelajaran Vokasional. Journal of Education and Instruction (JOEAI). [Online] 2 (1), 49-55. Available from: doi:10.31539/joeai.v2i1.614.

Yuliyanto, M. (2015) Audit Komunikasi Lembaga Pemerintah Kecamatan Tembalang, Kota Semarang. Jurnal Ilmu Sosial. [Online] 14 (1), 28-38. Available from: https://ejournal.undip.ac.id/index.php/ilmuso s/article/view/12754. 